\title{
POTENSI GANGGUAN WORK RELATED MUSCULOSKELETAL DISORDERS SELAMA BEKERJA DARI RUMAH BAGI AKADEMISI
}

\author{
Muhammad Dzaki Hidayatullah \\ Fakultas Kedoktern, Universitas Lampung, Jl. Prof. DR. Ir. Sumatri Brojonegoro No.1, Gedong Meneng, \\ Kec. Rajabasa, Kota Bandar Lampung, Lampung, Indonesia 35145 \\ dzakim39@gmail.com $(+6281379761789)$
}

\begin{abstract}
ABSTRAK
Gangguan muskuloskeletal terkait pekerjaan atau yang biasa disebut dengan work related musculoskeletal disorders saat ini menimbulkan tantangan bagi kesehatan masyarakat dan menimbulkan masalah keuangan, fisik dan sosial yang cukup besar bagi para pekerja. Ada kebutuhan untuk mendapatkan pengetahuan yang lebih mendalam mengenai hal ini di kalangan pekerja kantoran, untuk menanganinya dengan sukses. Berbagai penelitian yang meneliti tentang pengaruh gangguan penyakit musculoskeletal dan akademisi yang sangat relevan. Penelitian ini menggunakan metode systematic literature review yang terdiri dari 18 artikel Google Schoolar, Elsevier dan PubMed NCBI yang diterbitkan dari tahun 2012 hingga 2020. Kemudian dilakukan analisis terhadap artikel tersebut. Pada akhirnya didapatkan bahwa potensi gangguan work related musculoskeletal disorders disaat melakukan work from home.
\end{abstract}

Kata kunci: akademisi; bekerja dari rumah; penyakit muskuloskeletal

\section{POTENTIAL OF WORK RELATED MUSCULOSCELETAL DISORDERS DURING WORK FROM HOME FOR ACADEMICIAN}

\begin{abstract}
Work-related musculoskeletal disorders or what are commonly known as work-related musculoskeletal disorders currently pose challenges to public health and cause considerable financial, physical and social problems for workers. There is a need for more in-depth knowledge of this matter among office workers, to handle it successfully. Various studies examining the effects of musculoskeletal disorders and academia are highly relevant. This study uses a systematic literature review method consisting of 18 articles from Google Schoolar, Elsevier and PubMed NCBI published from 2012 to 2020. Then an analysis of the articles is carried out. In the end, it was found that the potential for work-related musculoskeletal disorders when working from home.
\end{abstract}

Keywords: academition; musculoskeletal disorders; work from home

\section{PENDAHULUAN}

Gangguan muskuloskeletal terkait pekerjaan atau work-related musculoskeletal disorders (WMSDs) saat ini menimbulkan tantangan bagi kesehatan masyarakat dan menimbulkan masalah keuangan, fisik dan sosial yang cukup besar bagi para pekerja. Ada kebutuhan untuk memperoleh pemahaman yang lebih dalam tentang hal ini di kalangan pekerja kantoran, untuk menanganinya dengan sukses. Survey yang dilakukan di Nigeria menyebutkan bahwa sekitar $70 \%$ dari pekerja kantoran Lembaga Pendidikan Tinggi mengalami penyakit ini terutama yang paling umum pada bagian lower back (Besharati et al., 2020). Berdasarkan the National Institute for Occupational Safety and Health United 
States, MSDs adalah penyakit terkait pekerjaan yang paling penting dan umum, MSDs juga menjadi salah satu penyebab utama dari ketidakhadiran dalam pekerjaan. Setiap pekerjaan pasti memiliki risiko kesehatan tersendiri. Para pekerja pelayanan kesehatan berisiko dalam perkembangan MSDs. Statistik menyebutkan satu pertiga dari pekerja pelayanan kesehatan merasa sakit yang berkaitan dengan MSDs (Jafari-Nodoushan et al., 2020).

Postur kerja yang tidak tepat telah dikaitkan dengan banyak hasil kesehatan yang merugikan termasuk gangguan muskuloskeletal. Meningkatnya prevalensi faktor risiko kesehatan terkait pekerjaan untuk gangguan muskuloskeletal mampu membatasi hasil kerja yang efektif terutama ketika intervensi yang memadai belum dilakukan untuk mengurangi manifestasi gejala gangguan ini. Pada negara Nigeria penelitian menyelidiki bahwa pengaruh kesehatan dari postur kerja tidak memiliki data epidemiologi yang dapat diandalkan terkait kesehatan pekerjaan. Maka dari itu, hal ini menunjukkan bahwa dibutuhkan penelitian untuk menentukan prevalensi gejala MSDs serta memastikan hubungannya dengan postur kerja para staff di Nigerian University (Ojule et al., 2020). Sedangkan di Malaysia Gangguan muskuloskeletal (MSD) telah menjadi masalah kesehatan kerja yang terkenal bagi para pekerja selama beberapa tahun terakhir, dan prevalensi nya di kalangan guru sangat tinggi. Di Malaysia beberapa studi berfokus pada MSDs dan faktor terkait antara guru sekolah, tetapi di trengganu. Tidak tersedia data untuk guru sekolah (Alias et al., 2020). Untuk sekarang istilah work from home bukanlah hal yang dianggap tabu oleh masyarakat.
Beberapa studi epidemiologi telah menemukan hubungan kausal aktivitas fisik pada saat bekerja dan gangguan MSDs terkait pekerjaan, beberapa faktor penyebabnya antara lain; gerakan berulang, tenaga yang dikeluarkan berlebihan, tegang, posisi yang dipertahankan serta duduk dan berdiri dalam waktu yang lama(Da Costa \& Vieira, 2010).

Penyakit Muskuloskeletal yang berkaitan dengan pekerjaan menimbulkan masalah pada otot, tendon, saraf jaringan sendi, fasia, dan ligamen. Prevalensi dari laporan mengenai permasalahan muskuloskeletal terjadi di beberapa negara. Namun, prevalensi gangguan kerja di negara berkembang belum terdokumentasi dengan baik karena keterbatasan yang terkait dengan diagnosis dan surveilans. Karena itu, instrumen sederhana seperti Nordic Musculoskeletal Questionnaire (NMQ) dibutuhkan menyaring dan mendeteksi permasalahan muskuloskeletal. NMQ sangat cocok diaplikasikan dalam penelitian partisipan yang sangat banyak (Kahraman et al., 2016).

Pengenalan workstation sit-to-stand telah menghasilkan komunitas tempat kerja memperdebatkan apakah berdiri sekarang adalah alternatif untuk duduk kerja (Tartaglia et al., 2019). Perdebatan ini tidak beralasan ketika manfaat dari perubahan yang sering terjadi postur tubuh dan menggunakan aliran darah untuk menjaga kesehatan fisik dan kognitif adalah hasil utama diperlukan. Istilah "pekerjaan dinamis" harus menjadi fokus dari berdebat untuk mendorong pekerja mengubah postur dan aktivitas kerja mereka menjadi menghasilkan aliran darah yang lebih besar dan menghilangkan beban otot statis (Gatchel \& Schultz, 2012). Ini 
seharusnya dibahas dalam debat kesehatan yang lebih luas dalam kaitannya dengan pencegahan kardio vaskular dan obesitas untuk pekerja yang tidak banyak bergerak. Ini adalah bagian dari fokus umum kesehatan dan kesejahteraan di tempat kerja (Lima Júnior \& Silva, 2014).

Pekerjaan dinamis bukan tentang duduk atau berdiri; mencakup kedua postur ini serta pemahaman pekerjaan yang lebih luas rancangan. Review aktivitas pekerja dalam penilaian pasca hunian baru calo kantor menunjukkan bahwa sekitar 50\% pekerja untuk tidak menyesuaikan mereka meja kerja duduk-untuk-berdiri tetapi biarkan pada ketinggian tempat duduk setiap saat. Ini pekerja menjelaskan bahwa desain pekerjaan mereka mengharuskan mereka sering berubah postur tubuh termasuk bangun dan berjalan-jalan (Andriani et al., 2020). Mereka mencapai manfaat pekerjaan dinamis melalui desain pekerjaan multi-tugas mereka. Sekitar $40 \%$ diindikasikan bahwa mereka akan menggunakan mekanisme penyesuaian untuk mengubah workstation tinggi badan antara duduk dan berdiri di siang hari, namun kemungkinannya kecil untuk menggunakan mekanisme penyesuaian jika berisik atau lambat untuk menyesuaikan. Sebenarnya waktu dan lamanya duduk atau berdiri tergantung dari fisik mereka, kebutuhan kognitif dan psikososial pekerja. Temuan juga mengungkapkan hal itu sekitar 10\% pekerja lebih suka berdiri di tempat kerja mereka semua waktu (DavudianTalab et al., 2017). Kelompok orang ini termasuk pekerja dengan cedera yang mengindikasikan hal itu duduk lama memperburuk kondisi mereka. Ini juga termasuk pekerja yang secara teratur duduk dalam pertemuan dan lebih suka berdiri ketika mereka kembali ke pertemuan mereka workstation untuk perubahan postur tubuh. Ada juga pekerja yang menggunakan luka-luka unit adaptor sit-to-stand pada workstation dengan ketinggian tetap, jika memang demikian pulih dari cedera. Terbukti desain beberapa unit adaptor dihadirkan Risiko MSD karena jumlah kekuatan dan ketinggian bahu yang dibutuhkan untuk menyesuaikan unit ini. Sehubungan dengan pelatihan ditemukan bahwa pengenalan workstation sit-to-stand memerlukan panduan khusus tentang cara mencapai dinamika kerja.

Pelatihan juga harus mengembangkan keterampilan untuk meredakan punggung bawah dan bawah kelelahan anggota badan karena berdiri terlalu lama. Ini sangat penting ketika file tangan berada di depan pusat gravitasi tubuh untuk bekerja pada keyboard dan mouse di permukaan kerja. Diperlukan penelitian lebih lanjut sebelum dan sesudah relokasi ke tempat kerja duduk untuk menilai dampak kesehatan dan kesejahteraan pada pekerja serta dampaknya pada produktivitas dan tuntutan kognitif mereka (Tartaglia et al., 2019).

Maka dari itu untuk memahami lebih dalam tentang potensi perlu diadakan penelitian penelitian terkait dengan dampak atau potensi yang ditimbulkan oleh work from home terhadap gangguan musculoskeletal akibat kerja

\section{METODE}

Pada penulisan ini penulis menggunakan metode article review. Kepustakaan didapat dari penelitian penelitian dari berbagai negara seperti Indonesia, Malaysia, Iran, Nigeria, dan Amerika Serikat. Tidak hanya dari penelitian sumber kepustakaan juga diambil dari buku yang berjudul Proceedings of the Ergonomics the 
International 20th Congress of Association (IEA 2018) yang ditulis oleh Riccardo Tartaglia, Sara Albolino, Thomas Alexander, dan Yushi Fujita dan diterbitkan oleh Springer yang dapat diakses melalui Google Scholar, Elsevier, dan NCBI. Dari 18 artikel yang diterbitkan tahun 2012 hingga 2020 dan artikel tersebutt di analisis dengan metode Systematic Literature Review dengan cara mengumpulkan sumber, melakukan evaluasi, dan melakukan pengembangan topik yang berfokus pada penelitian.

\section{HASIL}

Pada penelitian yang dilakukan oleh Alias pada tahun 2020 didapatkan hasil Guru perempuan di SD Terengganu menunjukkan prevalensi gangguan muskuloskeletal yang signifikan $(40,1 \%)$. Bagian tubuh yang paling terpengaruh adalah kaki, dengan 32,5\% selama 12 bulan terakhir dan 36,8\% selama 7 hari terakhir. Faktor risiko terkait seperti usia, BMI, aktivitas olahraga, jenis sepatu, jam mengajar dan jam berdiri dianalisis di antara para guru. Oleh karena itu,mereka lebih cenderung memiliki prevalensi MSD yang lebih tinggi daripada hasil saat ini karena faktor risiko yang signifikan jika tidak ada tindakan yang diambil untuk mengurangi prevalensi MSDs di antara para guru (Alias et al., 2020).

Pada penelitian Ojule tahun 2020 didapatkan Sebanyak $172 \quad(54,3 \%)$ responden pernah merasakan sakit muskuloskeletal dengan melibatkan kepala, leher, punggung, dan berbagai bagian tubuh lainnya. Selain itu, juga ditemukan hubungan yang signifikan secara statistik antara postur kerja dan kejadian sakit pada pelvis dan perineal. Postur kerja yang dinamis memberikan efek perlindungan dalam menghindari kejadian sakit pada thoraks dan abdominal (Ojule et al., 2020).

Pada penelitian Nana tahun 2017 didapatkan hasil analisis NBM memberikan informasi perubahan distribusi tingkat keluhan muskuloskeletal disorder (MSDs) operator sebelum bekerja dan setelah bekerja. Jenis keluhan paling dominan untuk tingkat keluhan baik sebelum maupun setelah bekerja adalah sakit pada pinggang (Rahdiana et al., 2016) dan Hasil penelitian menunjukkan bahwa tingkat risiko MSDs pada operator mesin potong guillotine $63 \%$ kategori rendah $37 \%$ kategori sedang (Rahdiana, 2017).

Pada penelitian Kahraman dkk didapatkan Konsistensi internal sempurna dengan cronbach alpha= 0,896. Reabilitas dinilai dengan prevalence-adjusted bias-adjusted kappa (PABAK). Partisipan dengan permasalahan muskuloskeletal pada bagian terkait relevan dengan kuesioner. Hal ini mengindikasikan bahwa NMQ memiliki validitas konstruk yang baik (Kahraman et al., 2016).

\section{PEMBAHASAN}

Pada penelitian yang dilakukan oleh ojule tahun 2016 Dalam studi ini didapatkan gejala gangguan muskuloskeletal (MSDs) di antara pekerja di University of Port Harcourt. Ditemukan bahwa sebagian besar staf pernah mengalami gejala muskuloskeletal melibatkan daerah kepala, leher dan punggung tubuh mereka. Daerah lain dari tubuh juga mengalami gejala gangguan muskuloskeletal di antara responden termasuk toraks, daerah perut, panggul, perineum dan tungkai. Temuan ini dikonfirmasi oleh penelitian sebelumnya di wilayah yang sama yang 
juga dilaporkan tinggi prevalensi gangguan muskuloskeletal gejala di antara populasi penelitian mereka (Ephraim-Emmanuel \& Douglas, 2018). Peneliti di belahan dunia lain juga melaporkan prevalensi gejala MSDs yang tinggi di antara pekerja (Waters \& Dick, 2015). Implikasi dari ini temuan itu baik administratif maupun akademis anggota staf Universitas Port Harcourt terkena postur kerja ergonomis yang buruk dan karena itu rentan terhadap MSD dan lainnya kondisi tidak menular. Itu terkenal yang sebagian besar akademik dan administrasi kegiatan di tempat seperti universitas dilakukan keluar secara menetap, dengan sebagian besar waktu kerja dihabiskan di kursi mereka dan meja.

Mengajar juga dilakukan dalam postur statis (duduk atau berdiri) dengan sisa waktu di kantor dosen. Konferensi tahun 2016 tentang faktor manusia dan ergonomi menegaskan bahwa peregangan panjang dalam postur tertentu seperti penggunaan mouse dan keyboard dalam waktu lama, berjamjam pada pertemuan dan kegiatan akademik lainnya bersama dengan beban kerja dan stres yang tinggi faktor risiko kontribusi untuk pengembangan gangguan muskuloskeletal yang berhubungan dengan pekerjaan (Waters \& Dick, 2015). Beragamnya aktivitas yang dilakukan dirumah, baik dalam melakukan pekerjaan rutin di rumah maupun pekerjaan kantor dapat mengakibatkan cedera terutama gangguan muskuloskeletal. Gangguan muskuloskeletal (Musculoskeletal Disorders / MSDs) adalah cedera atau disfungsi yang mencakup spektrum yang luas dari kondisi inflamasi dan degeneratif yang mempengaruhi otot, tendon, ligament, sendi, syaraf tepi dan berhubungan dengan pembuluh darah (Sirajudeen et al., 2018).

\section{SIMPULAN}

Setelah dilakukan analisis terhadap 18 artikel yang diterbitkan tahun 2012 hingga 2020, pada masa work from home akademisi tidak hanya melakukan pekerjaannya saja melainkan melakukan pekerjaan rumah serta pekerjaan kantor yang biasanya bisa menghabiskan waktu hingga berjam jam untuk duduk dan menyelesaikan pekerjaan kantor dan juga mengajar dan dengan demikian dapat disimpulkan bahwa adanya potensi antara work from home dan gangguan work related musculoskeletal disorders di kalangan akademisi sangat relevan.

\section{DAFTAR PUSTAKA}

Alias, A. N., Karuppiah, K., How, V., \& Perumal, V. (2020). Prevalence of musculoskeletal disorders (MSDS) among primary school female teachers in Terengganu, Malaysia. International Journal of Industrial Ergonomics, 77(December 2019), 102957. https://doi.org/10.1016/j.ergon.20 20.102957

Andriani, B., Camelia, A., \& Faisya, H. . F. (2020). Analysis of Working Postures with Musculoskeletal Disorders (Msds) Complaint of Tailors in Ulak Kerbau Baru Village, Ogan Ilir. Jurnal Ilmu Kesehatan Masyarakat, 11(01), 75-88.

https://doi.org/10.26553/jikm.202 0.11.1.75-88

Besharati, A., Daneshmandi, H., Zareh, K., Fakherpour, A., \& Zoaktafi, M. (2020). Work-related musculoskeletal problems and associated factors among office workers. International Journal of Occupational Safety and Ergonomics, 26(3), 632-638. https://doi.org/10.1080/10803548. 
2018.1501238

Da Costa, B. R., \& Vieira, E. R. (2010). Risk factors for work-related musculoskeletal disorders: A systematic review of recent longitudinal studies. American Journal of Industrial Medicine, 53(3), 285-323. https://doi.org/10.1002/ajim.2075 0

Davudian-Talab, A., Azari, G., Badfar, G., Shafeei, A., \& Derakhshan, Z. (2017). Evaluation and Correlation of the Rapid Upper Limb Assessment and Rapid Office Strain Assessment Methods for Predicting the Risk of Musculoskeletal Disorders. Internal Medicine and Medical Investigation Journal, 2(4), 155. https://doi.org/10.24200/imminv.v $2 \mathrm{i} 4.87$

Ephraim-Emmanuel, B. C., \& Douglas, K. E. (2018). Prevalence of Reported Symptoms of Musculoskeletal Disorders among Doctors at the University of PortHarcourt Teaching Hospital, Nigeria. Journal of Advances in Medicine and Medical Research, 28(1).

https://doi.org/10.9734/jammr/201 $8 / 45210$

Gatchel, R. J., \& Schultz, I. Z. (2012). Handbook of occupational health and wellness. Handbook of Occupational Health and Wellness, 1-576. https://doi.org/10.1007/978-14614-4839-6

Jafari-Nodoushan, A., Bagheri, G., \& Mosavi Nodoushan, fatemesadat. (2020). Effect of COVID-19 virus on Prevalence of Musculoskeletal Disorders of Faculty Members of
Yazd University. Journal of Ergonomics, 8(3), 1-12. https://doi.org/10.30699/jergon.8. 3.1

Kahraman, T., Genç, A., \& Göz, E. (2016). The Nordic Musculoskeletal Questionnaire: cross-cultural adaptation into Turkish assessing its psychometric properties. Disability and Rehabilitation, 38(21), 2153-2160. https://doi.org/10.3109/09638288. 2015.1114034

Lima Júnior, J. P. de, \& Silva, T. F. A. da. (2014). Analysis of musculoskeletal disorders symptoms in professors of the University of Pernambuco Petrolina Campus. Revista Dor, 15(4), 276-280. https://doi.org/10.5935/18060013.20140060

Ojule, I. N., Dokubo, S. S., \& Emmanuel, B. C. E.-. (2020). Prevalence of Musculoskeletal Disorder Symptoms and Relationship with Work Posture among Staff of a Nigerian University. International Journal of TROPICAL DISEASE \& Health, 41(14), 1-8. https://doi.org/10.9734/ijtdh/2020/ v41i1430348

Otten, C., Brilli, M., Vollmer, W., Viollier, P. H., \& Salje, J. (2018). Peptidoglycan in obligate intracellular bacteria. Molecular Microbiology, 107(2), 142-163. https://doi.org/10.1111/mmi.1388 0

Rahdiana, N. (2017). Identifikasi Risiko Ergonomi Operator Mesin Potong Guillotine Dengan Metode Nordic Body Map ( Studi Kasus Di Pt . 
Xzy ). IndustryXplore, 02(01), 112.

Rahdiana, N., Mayasari, D., Saftarina, F., Alias, A. N., Karuppiah, K., How, V., Perumal, V., Maiti, Bidinger, Kahraman, T., Genç, A., \& Göz, E. (2016). Identifikasi Risiko Ergonomi Operator Mesin Potong Guillotine Dengan Metode Nordic Body Map ( Studi Kasus Di Pt . Xzy ). Disability and Rehabilitation, 53(21), 16891699.

https://doi.org/10.1016/j.ergon.20 20.102957

Sirajudeen, M. S., Alaidarous, M., Waly, M., \& Alqahtani, M. (2018). Work-related musculoskeletal disorders among faculty members of college of Applied Medical Sciences, Majmaah University, Saudi Arabia: A cross-sectional study. International Journal of Health Sciences, 12(4).

Tartaglia, R., Albolino, S., Alexander, T., \& Fujita, Y. (2019). 20th Congress of the International Ergonomics Association, IEA 2018. In Advances in Intelligent Systems and Computing (Vol. 824 , Issue Iea).

Waters, T. R., \& Dick, R. B. (2015). Evidence of health risks associated with prolonged standing at work and intervention effectiveness. Rehabilitation Nursing, $\quad 40(3)$. https://doi.org/10.1002/rnj.166 
Jurnal Penelitian Perawat Profesional, Volume 3 No 2 Hal 311 - 318, Mei 2021 Global Health Science Group 